Cell Research (2002); 12(2):151-156

http://www.cell-research.com

\title{
The intracellular mechanism of alpha-fetoprotein promoting the proliferation of NIH 3T3 cells
}

\author{
Meng Sen LI ${ }^{1}$, Ping Feng LI ${ }^{1}$, Fei Yi YANG ${ }^{1}$, Shi Peng HE², Guo Guang DU ${ }^{1}$, Gang LI1,* \\ ${ }^{1}$ Department of Biochemistry and Molecular Biology, 2Department of Biophysics, Health Science Center, Peking \\ University, Beijing 100083, China
}

\begin{abstract}
AIM The existence and properties of alpha-fetoprotein (AFP) receptor on the surface of NIH 3T3 cells and the effects of AFP on cellular signal transduction pathway were investigated. METHODS The effect of AFP on the proliferation of NIH 3T3 cells was measured by incorporation of ${ }^{3} \mathrm{H}-\mathrm{TdR}$. Receptor-binding assay of ${ }^{125} \mathrm{I}$-AFP was performed to detect the properties of AFP receptor in NIH 3T3 cells. The influences of AFP on the [cAMP]i and the activities of protein kinase A (PKA) were determined. Western blot was used to detect the change of K-ras P21 protein expression. RESULTS The proliferation of NIH 3T3 cells treated with $0-80 \mathrm{mg} / \mathrm{L}$ of AFP was significantly enhanced. The Scatchard analysis indicated that there were two classes of binding sites with $\mathrm{K}_{D}$ of $2.722 \times 10^{-9} \mathrm{M}(\mathrm{Bmax}=12810$ sites per cell $)$ and $8.931 \times 10^{-8} \mathrm{M}(\mathrm{Bmax}=119700$ sites per cell) respectively. In the presence of AFP $(20 \mathrm{mg} / \mathrm{L})$, the content of cAMP and activities of PKA were significantly elevated. The level of K-ras P21 protein was upregulated by AFP at the concentration of $20 \mathrm{mg} / \mathrm{L}$. The monoclonal antibody against AFP could reverse the effects of AFP on the cAMP content, PKA activity and the expression of K-ras p21 gene. CONCLUSION The effect of AFP on the cell proliferation was achieved by binding its receptor to trigger the signal transduction pathway of cAMP-PKA and alter the expression of K-ras p21 gene.
\end{abstract}

Key words: Alpha-fetoprotein, receptor, signal transduction, monoclonal antibody, gene expression.

\section{INTRODUCTION}

Alpha-fetoprotein (AFP) is a cancer-associated fetal glycoprotein, normally produced in the fetal liver and yolk sac, and its high serum level is a useful clinical marker for hepatocellular carcinoma and yolk sac tumor. Although the physicochemical and structural properties of this 62-72 kDa glycoprotein have been largely documented, only in vitro functional roles of this oncofetal protein have been ascertained to date. Such physiological properties of

\footnotetext{
* Corresponding authors: Gang LI and Ping-feng LI. Department of Biochemistry and Molecular Biology, Health Science Center. Peking University, 38 Xueyan Rd, Beijing 100083, China. Phn 86-01-62092454. E-mail: ligang55@263.net or 55ligang@163.com Abbreviations: AFP: alpha-fetoprotein, HSA: human serum albumin, Anti-AFP: monoclonal antibody.

Received Aug-27-2001 Revised April-15-2002 Accepted April18-2002
}

the oncofetal protein have encompassed mainly ligand carrier/transport function and modulation of in vitro immune response assays. In the last decade, the growth regulatory properties of AFP have aroused interest as a result of studies involving ontogenetic and oncogenic growth in both cell culture and animal models[1-3].A myriad of studies have now described that AFP is capable of regulating growth in ovarian, placental, urerine, hepatic phagocytic, bone marrow, and lymphatic cells[4] in addition to various neoplastic cells[5]. AFP should no longer be considered merely a fetal form of albumin only to be employed as a marker for cancer and fetal disorders. Rather, AFP should now be considered as a possible direct or indirect factor associated with the regulation of growth, differentiation, regeneration, and transformation in both ontoge- 
netic and oncogenic growth processes. However, little information regarding the biochemical features of alpha-fetoprotein determined using molecular biological techniques is available. Although it is currently thought that a 62 - to $67-\mathrm{kDa}$ membrane protein on the surface of monocytes and phagocytes is specific for AFP [6-7], the properties of the binding sites were still unknown in most tumor cell lines. Furthermore, few studies have focused on its intracellular signaling events and gene expression. The goal of this study was to characterize the AFP receptor, its possible signal transduction pathway and its proliferous functions in human NIH 3T3 cells.

\section{MATERIALS AND METHODS}

\section{Reagents}

The cAMP CPBA kit and $\mathrm{Na}\left[{ }^{125} \mathrm{I}\right]$ were purchased from Amersham, UK. Fluo-3 AM ester was from BioRad (USA). Purified AFP was from Sigma (USA). Monoclonal antibody for K-ras P21 protein was purchased from Maxim Biotech, Inc (USA).

\section{Isolation and identification of human AFP}

Human AFP was prepared by the method as described elsewhere[8]. Briefly, human cord blood AFP was precipitated by ammonium sulphate and passed through an anti-AFP affinity chromatography column. AFP-positive fractions were collected and concentrated. The purity of prepared AFP was $92.7 \%$ determined by sodium dodecyl sulfate-polyacrylamide gel electrophoresis. The protein was stored at $-80^{\circ} \mathrm{C}$ until use.

\section{Preparation of monoclonal antibody against AFP}

Monoclonal antibody against AFP (Anti-AFP) was prepared according to the routine procedure[9]. In short, BABL/C mice was immunized with purified AFP (Sigma) in complete Freunds adjuvant at 2 to $3 \mathrm{w}$ intervals. The spleen cells separated from mice were fused with myeloma cells to form a stable antibodyproducing hybridoma cell line. Positive clones were screened by the method of ELISA and inoculated into BALB/C mice. The antiAFP was harvested from ascites fluid and purified with affinity chromatography. The specificity of monoclonal antibody with a titers higher than 5000 for AFP was ascertained by ELISA and Western blotting assay to obviate the interference of albumin which had a similar structure to AFP. The results in ELISA and Western blotting assay showed the specific binding of monoclonal antibody to AFP and negative reaction to albumin(data not show).

\section{Measurement of the cellular proliferation}

NIH 3T3 cells were suspended in RPMI-1640 medium (containing $10 \%$ fetal calf serum) and added into 24 -well plate at $1 \mathrm{ml}$ per well followed by incubating at $37^{\circ} \mathrm{C}$ in a humidified atmosphere of $5 \% \mathrm{CO}_{2}$ for $48 \mathrm{~h}$. The supernatant was removed and replaced with $150 \mu \mathrm{l}$ of fresh medium (without fetal calf serum) for another $24 \mathrm{~h}$. Different concentrations of AFP $(0-80 \mathrm{mg} / \mathrm{L})$, human serum albumin (HSA) or Anti-AFP were administrated into each well respectively for $20 \mathrm{~h}$ and then pulsed with $1 \mathrm{mCi}$ of $3 \mathrm{H}$ $\mathrm{TdR}$. The cells were harvested $4 \mathrm{~h}$ later onto glass microfiber filter using a multiple sample harvester. The incorporation of ${ }^{3} \mathrm{H}-\mathrm{TdR}$ was measured by using LKB 1209 Rackbeta liquid scintillation counter. To determine whether the influence of AFP on the proliferation was specific, the blockage of Anti-AFP and HSA as a structure analog were also used as controls.

\section{AFP receptor binding assay}

$\mathrm{NIH} 3 \mathrm{~T} 3$ cells were maintained in suspension cultures at $37^{\circ} \mathrm{C}$ in RPMI-1640 medium without serum for $12 \mathrm{~h}$ and washed three times with cold medium. Resuspended cells were passed through a 300 mesh screen and adjusted to $1 \times 10^{6}$ cells per ml. ${ }^{125}$ I-AFP was prepared by the iodogen method and run through a column of Sephadex-G25 to remove some of the unincorporated ${ }^{125}$ I. The specific activity of ${ }^{125} \mathrm{I}$-AFP was $2715 \mathrm{Ci}$ per mmol and the radiochemical purity of ${ }^{125} \mathrm{I}$ was $99.4 \%$. Each reaction contained $7 \times 10^{5}$ cells, ${ }^{125} \mathrm{I}$-AFP of $10^{-15} \mathrm{M}\left(5 \times 10^{4} \mathrm{cpm}\right)$ and different concentrations of non-labeled AFP (0.25-64.5 ng). The reactions were triplicated and performed at $4{ }^{\circ} \mathrm{C}$ for $2 \mathrm{~h}$. Nonspecific binding was determined using $2 \mu$ g.ml-1 partially purified AFP (90\% purification) per well. All samples were collected onto glassfiber (saturated with $0.5 \%$ albumin in advance) and washed three times with $15 \mathrm{ml}$ of PBS. The radioactivity of ${ }^{125} \mathrm{I}$ was detected by a -counter.

\section{Extraction and detection of cAMP}

Cells were adjusted to $4 \times 10^{4}$ cells per ml with medium (containing $10 \%$ fetal calf serum) and aliquot into 24 well plates to incubate for $24 \mathrm{~h}$. The supernatant was removed and resuspended in the medium supplemented with $0.1 \%$ egg albumin and $2.5 \times 10^{-2} \mathrm{M}$ of HEPES and $2 \mathrm{mM}$ IBMX (3-methyl-1-isobutyl-xanthine) at $37^{\circ} \mathrm{C}$ for $15 \mathrm{~min}$. AFP (20 mg/L) or Anti-AFP (40 mg/L) were administrated into each well respectively for $4 \mathrm{~h}$. Extraction of cAMP was performed according to the method described by Iwashita[10]. In short, the supernatant was removed and replaced with $1 \mathrm{ml}$ of cold PBS per well. After wash 3 times, the pellet was frozen in -80 ${ }^{\circ} \mathrm{C}$ for $30 \mathrm{~min}$ and then added $0.5 \mathrm{ml}$ of $\mathrm{HCl}(0.05 \mathrm{~N})$ into each well for another $30 \mathrm{~min}$ in $-80^{\circ} \mathrm{C}$. The samples were melted in room temperature and transferred into eppendorf tubes. The supernatant for each sample was taken out following the spin at $10000 \mathrm{~g}$ for $5 \mathrm{~min}$ and lyophilized. The content of cAMP was determined by the radio-immunoassay according to the instruction of cAMP detection kit.

\section{Determination of protein kinase A activity}

NIH 3T3 cells were adjusted to a final concentrations of $4 \times 10^{4}$ cells per ml with RPMI-1640 (containing 10\% fetal calf serum) in culture plates for $48 \mathrm{~h}$ and then resuspended in medium without serum for $24 \mathrm{~h}$. The cells were administrated with AFP $(20 \mathrm{mg} / \mathrm{L})$, Anti-AFP (40 mg/L) or AFP (20 mg/L) plus Anti-AFP (40 mg/L) respectively. After being treated for 2, 6,12 and $24 \mathrm{~h}$, the cells were washed and resuspended in $1 \mathrm{ml}$ of PBS (0.15 M, pH 7.4). The 
measurement of PKA activity has been carried out as described in Park et al with modifications[11]. Briefly, $40 \mu$ l of extracted enzyme fractions were mixed with $160 \mu \mathrm{l}$ of the solution at the final concentration of $2.0 \times 10^{-2} \mathrm{M}$ Tris- $\mathrm{HCl}\left(\mathrm{pH} 7.5\right.$ ), $5 \times 10^{-3} \mathrm{M} \mathrm{MgCl}_{2}, 0$. $25 \mathrm{~g} / \mathrm{L}$ BSA, $0.5 \mathrm{~g} / \mathrm{L}$ histone, $2 \times 10^{-7} \mathrm{M}$ ATP $\left({ }^{32} \mathrm{P}\right.$ ATP, $\left.3.7 \times 10^{4} \mathrm{~Bq}\right)$ and $8.0 \times 10^{-6} \mathrm{M}$ cAMP at $37^{\circ} \mathrm{C}$ for $10 \mathrm{~min}$. After being followed by incubation on ice for $5 \mathrm{~min}$ to terminate the reaction, $150 \mu \mathrm{l}$ of the solution from each sample was collected onto Whatmen GF/C filter paper. After washing $2 \times$ with $10 \%$ TCA- $2 \%$ phosphoric acid for $30 \mathrm{~min}$ at room temperature followed by $2 \times$ wash with $5 \% \mathrm{TCA}$ for $30 \mathrm{~min}$, the activities of PKA were measured by liquid scintillation counter and expressed as pmol value of ${ }^{32} \mathrm{P}$ in histone catalyzed by per mg protein per min.

\section{Western blot immunodetection}

$1 \times 10^{5}$ cells per $\mathrm{ml}$ were maintained in RPMI-1640 medium without serum at $37^{\circ} \mathrm{C}$ for $12 \mathrm{~h}$. Then, the cells were treated with $\operatorname{AFP}(20 \mathrm{mg} / \mathrm{L})$, Anti-AFP (40 mg/L) or AFP (20 mg/L) plus Anti$\operatorname{AFP}(40 \mathrm{mg} / \mathrm{L})$ respectively for $24 \mathrm{~h}$. After three times wash, the cells in each reaction were incubated in $10 \mu \mathrm{l}$ of lysis buffer containing $0.2 \%$ Triton X-100, $0.5 \mathrm{M} \mathrm{NaCl}, 0.5 \mathrm{M}$ sucrose, $1 \times 10^{-3}$ $M$ EDTA, $1.5 \times 10^{-4} \mathrm{M}$ specimine, $5 \times 10^{-4} \mathrm{M}$ spermidine, $1.0 \times 10^{-2} \mathrm{M}$ HEPES (pH 8.0), $2.0 \times 10^{-4} \mathrm{M}$ phenylmethylsulfonyl fluoride, $2 \mathrm{mg}$ leupeptin $/ \mathrm{ml}, 2 \mu \mathrm{g}$ pepstatin $/ \mathrm{ml}, 24 \mathrm{IU}$ aprotinin $/ \mathrm{ml}$ and $7 \times 10^{-3} \mathrm{M}$ $\beta$-mercaptoethanol. $40 \mathrm{mg}$ of total proteins were subjected to sodium dodecyl sulfate-polyacrylamide gel electrophoresis (SDSPAGE) and transferred to PVDF membrane for immunodetection. SDS-PAGE molecular weight markers (Bio-Rad) verified the correct location of the visualized bands. The membranes were blocked in 5\% carnation nonfat milk (w/v) in PBS-Tween, probed with anti-K-ras P21 antibody and followed by second antibody (Goat anti-mouse Ig-alkaline phosphatase). Immunoreaction protein was detected by the color develop system (NBT/BCIP). Quantitative analysis of bands were performed by an automated digitizing system (UN-SCAN-IT, Silk Scientific, Inc.) and expressed with pix total.

Statistical analysis Data were expressed as mean \pm s obtained from at least 3 or 4 independent experiments and analyzed by $t$ test.

\section{RESULTS}

\section{The effect of AFP on the cellular proliferation}

After treatment of NIH 3T3 cells with AFP for 24 $\mathrm{h}$, the proliferation of NIH $3 \mathrm{~T} 3$ cells could be markedly enhanced in a dose dependent manner. The extents of increase were up to $21.0-121.9 \%$ compared with the control group (Fig 1). HSA could not show the obvious influences on the proliferation. Although Anti-AFP alone did not change the incor- poration of ${ }^{3} \mathrm{H}$-TdR, the effect of AFP could be reversed by Anti-AFP (Fig 2).

\section{Distribution of AFP receptor on the membranes of NIH $3 T 3$}

The binding sites of AFP on the surface of the cell and $\mathrm{K}_{D}$ values were calculated based on the Scatchard plot analysis of ${ }^{125} \mathrm{I}-\mathrm{AFP}$. According to the Scatchard analysis, there were two classes of receptors with $\mathrm{K}_{D} 2.722 \times 10^{-9} M$ (with 12810 sites per cell) and $\mathrm{K}_{D}$ $8.931 \times 10^{-8} M$ (119700 sites per cell) (Fig 3 ).

\section{Determination of intracellular cAMP concentration}

AFP could markedly elevated the concentrations of cAMP up to $267 \%$ in NIH 3T3 cells (Fig 4). Anti-

\section{AFP could markedly elevated the concentrations}

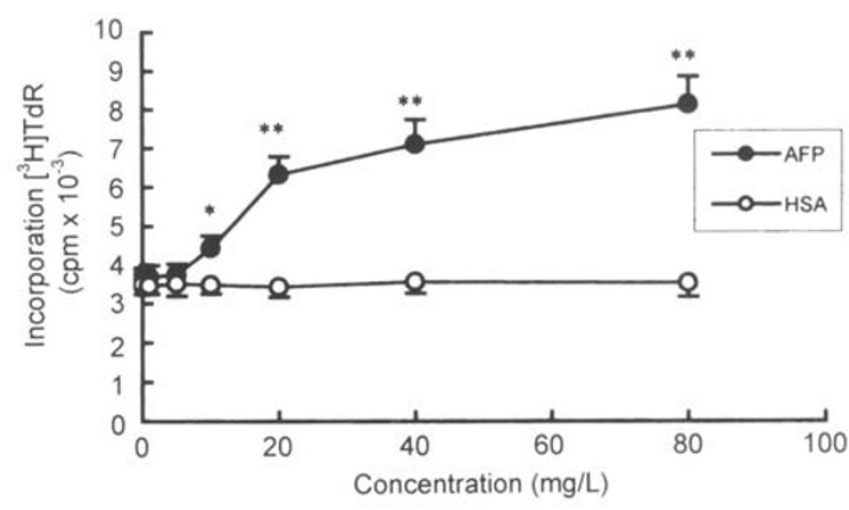

Fig 1. The effects of different concentrations $(0-80 \mathrm{mg} / \mathrm{L})$ of AFP or HSA on the incorporation of ${ }^{3} \mathrm{H}-\mathrm{TdR}$ into DNA in $\mathrm{NIH}$ 3 T3 cells. $\mathrm{n}=6, * \mathrm{P}<0.05$ and $* * \mathrm{P}<0.01$ vsdosage $0 \mathrm{mg} / \mathrm{L}$.

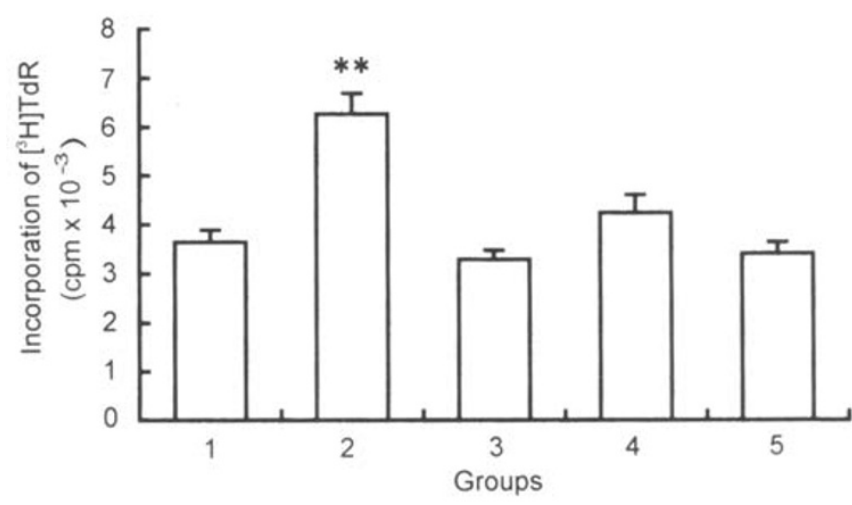

Fig 2. The blockage effects of Anti-AFP to AFP on the proliferation of NIH 3T3 cells. Treated groups: 1. control; 2. AFP $(20 \mathrm{mg} / \mathrm{L}) ; 3$. Anti-AFP $(40 \mathrm{mg} / \mathrm{L}) ; 4$. AFP $(20 \mathrm{mg} /$ $\mathrm{L})+\operatorname{Anti}-\mathrm{AFP}(40 \mathrm{mg} / \mathrm{L}) ; 5$. HSA $(20 \mathrm{mg} / \mathrm{L}) . \mathrm{n}=6$; * $\mathrm{P}<0$. 01 vs control group. 
AFP could not alter the concentrations of cAMP, but it could reverse the effect of AFP. HSA did not influence the concentration of cAMP.

\section{Detection of PKA activity}

The activities of PKA in the cytosol of NIH 3T3 cells was obviously elevated after treated with AFP for 2, 6, 12 or $24 \mathrm{~h}$ (Fig 5). The activities of PKA were respectively increased up to $14.8,81.1,63.3$ and $14.9 \%$ at each time point. The peak value was achieved at $6 \mathrm{~h}$ and then declined gradually, but still maintained a higher activity for several hours. Anti-

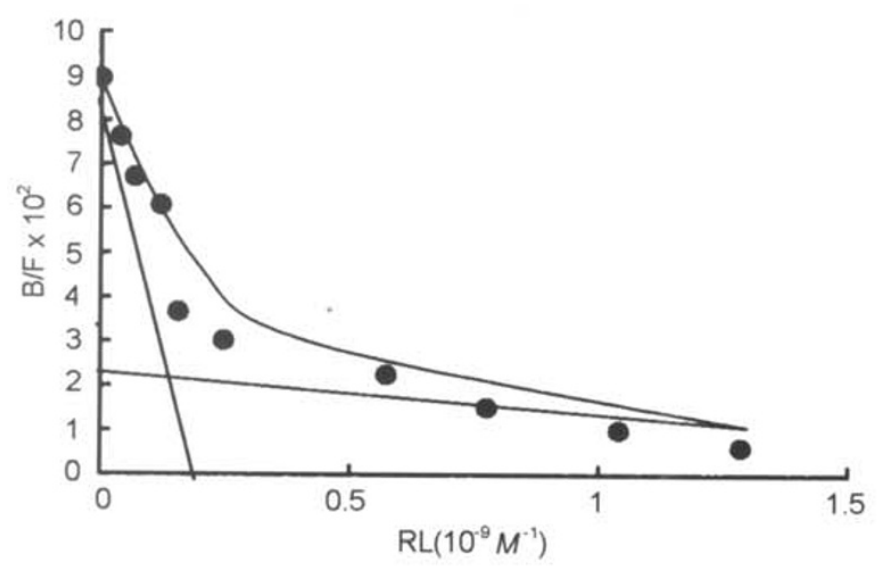

Fig 3. Scatchard analysis of ${ }^{125} \mathrm{I}-\mathrm{AFP}$ binding to NIH $3 \mathrm{~T} 3$ cells. The properties of AFP receptor was detected with receptor binding assay and analyzed by a program of Radioligand Binding Assay of Receptor. The data was selected from three independent experiments.

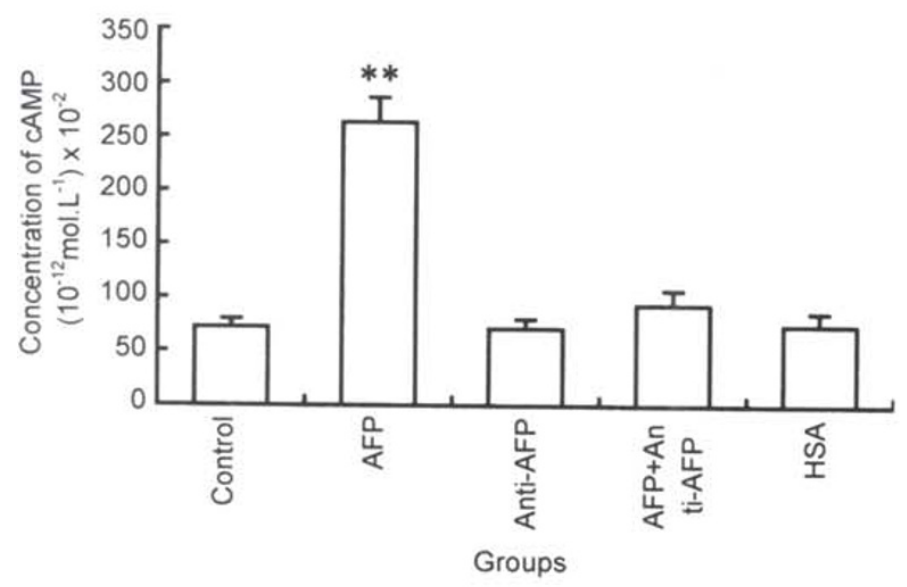

Fig 4. The effects of AFP ( $20 \mathrm{mg} / \mathrm{L})$, Anti-AFP ( $40 \mathrm{mg} / \mathrm{L})$, AFP $(20 \mathrm{mg} / \mathrm{L})+\operatorname{Anti}-A F P(40 \mathrm{mg} / \mathrm{L})$ or HSA $(20 \mathrm{mg} / \mathrm{L})$ on the cAMP concentration of NIH 3T3 cells. Data presented as mean values of 8 samples $\pm \mathrm{s}$. ** $\mathrm{P}<0.01$ vscontrol.
AFP monoclonal antibody and HSA did not obviously influence the activity of PKA, but Anti-AFP could block the effects of AFP on the activity of PKA.

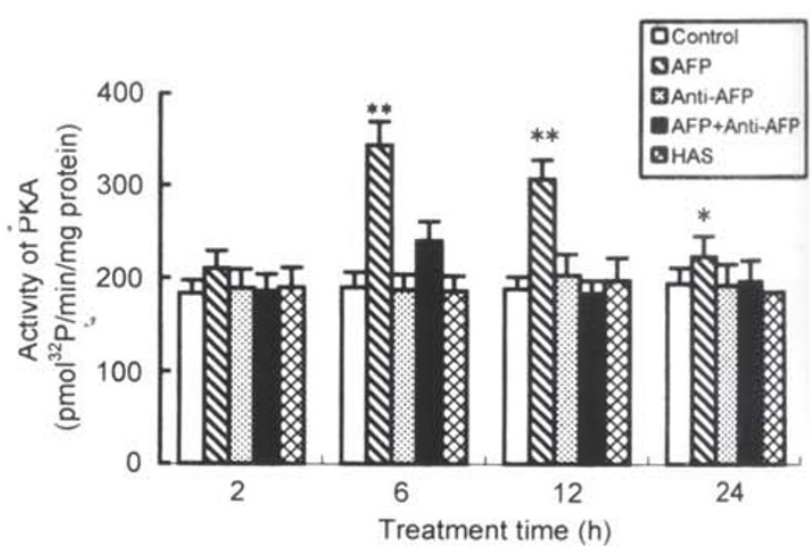

Fig 5. The effects of AFP (20 mg/L), Anti-AFP (40 mg/L), AFP $(20 \mathrm{mg} / \mathrm{L})+$ Anti-AFP $(40 \mathrm{mg} / \mathrm{L})$ or HSA $(20 \mathrm{mg} / \mathrm{L})$ on the PKA activity of NIH 3T3 cells. * $\mathrm{P}<0.05$ and $* * \mathrm{P}<0.01$ vs control. Data presented as mean values of 4 samples $\pm \mathrm{s}$.
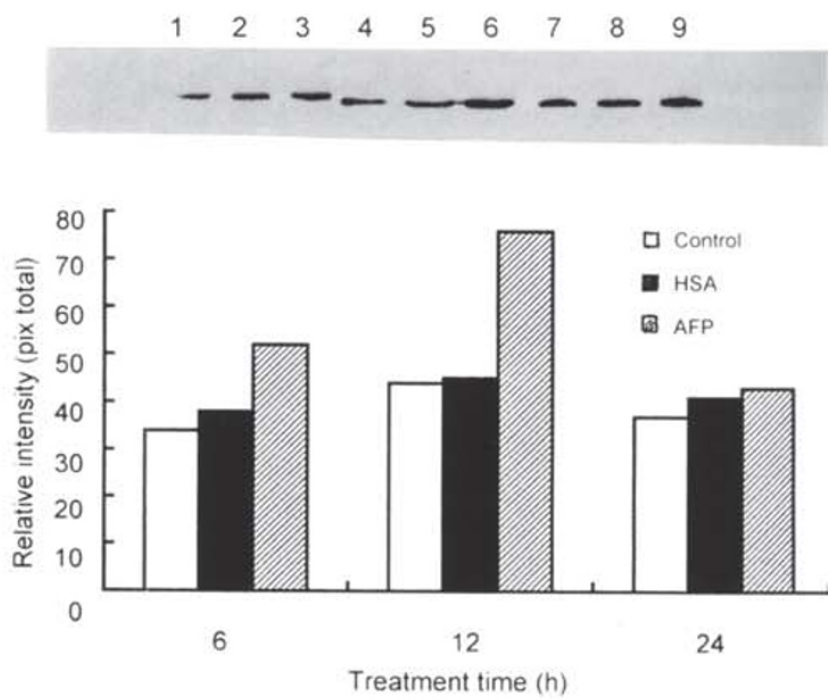

Fig 6. The cells were treated with $\mathrm{HSA}(20 \mathrm{mg} / \mathrm{L})$ or $\mathrm{AFP}(20$ $\mathrm{mg} / \mathrm{L}$ ) for 6,12 or $24 \mathrm{~h}$. The effect of AFP on the expression of K-ras P21 proteins in NIH 3T3 cells was detected by Western blot assay. Relative intensity for each band was determined by an automated digitizing system. The data was selected from four similar experiments. 
Determination on the expression of K-ras P21 proteins

The result in Fig 6 demonstrated the overexpression of K-ras P21 protein in AFP-treated group in NIH $3 \mathrm{~T} 3$ cells at different treated time (Fig 6 ). The upregulated effects of AFP on the expression of K-ras p21 gene could be blocked by AntiAFP (Fig 7). HSA could not influence the contents of this protein. Each figure was selected from 3 similar results.
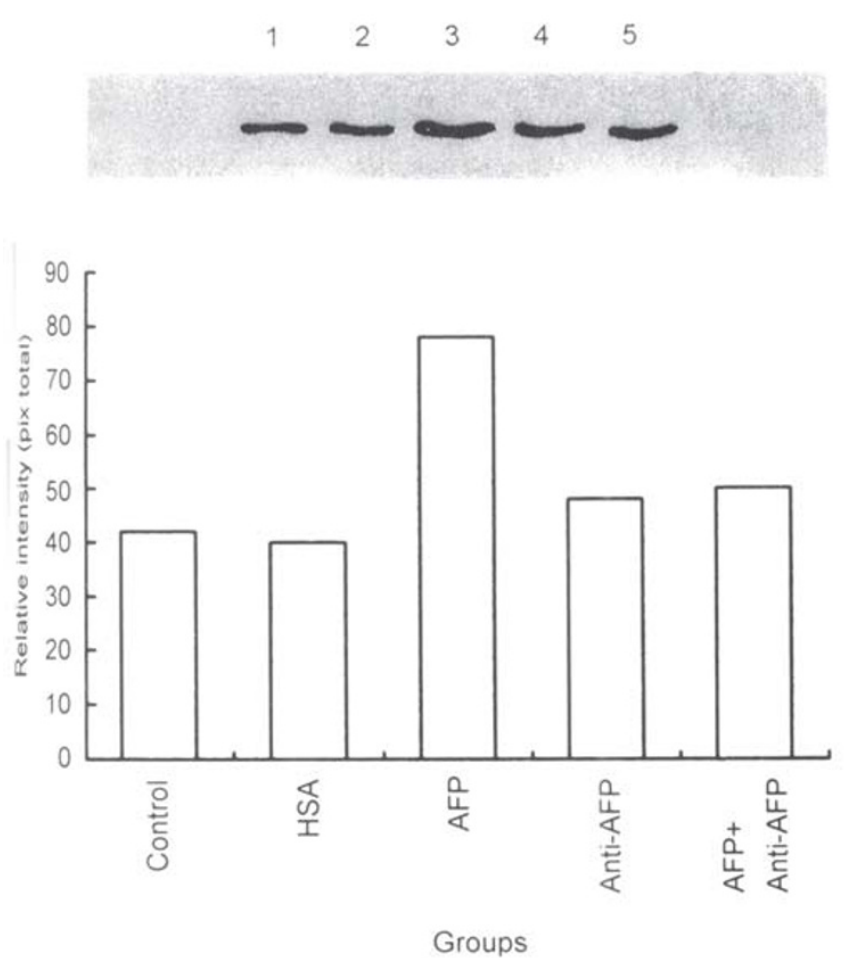

Fig 7. The effects of AFP on the expression of K-ras P21 proteins in NIH 3T3 cells were detected by Western blot assay. Relative intensity for each band was determined by an automated digitizing system. Treated groups: Control, control group; HAS, HSA treated group; AFP, AFP treated group; Anti-AFP, Anti-AFP treated group; AFP + Anti-AFP, AFP plus Anti-AFP treated group. The data was selected from four similar experiments.

\section{DISCUSSION}

$\mathrm{AFP}$, as an oncodevelopmental gene product which is expressed at high levels in the adult during liver regeneration and hepatocarcinogenesis, has been recently revealed as a protein with growth factor-like. Although the biological regulation of AFP on the cell growth has been extensively evaluated[8], [12-14] and verified by our results of the cellular prolifera- tion assay, neither the properties of AFP receptor in tumor cells were fully clarified, nor the subsequent events was tested after AFP binding the receptor. Some recent investigations of AFP-receptor have emerged which documented the existence and further characterized the nature of such binding protein. Our data revealed that there were two classes of receptors in cultured NIH 3T3 cells. Scatchard analysis displayed the presence of two specific AFP binding site classes with $\mathrm{K}_{D}$ of $10^{-9}$ and $10^{-8} \mathrm{M}$, which was consistent with some similar experiments that characterized the $\mathrm{K}_{D}$ of binding protein in the monocytes were at a range of $10^{-11}-10^{-}$ ${ }^{7} \mathrm{M}[6]$, [15].

Little information about the effect of AFP on the signal transduction was available to explain the intracellular mechanism. In the present experiment, the evidences that the activities of PKA and the content of cAMP in the NIH 3T3 cells were significantly elevated indicated a cAMP-dependent protein kinase pathway was involved in the effects of AFP on the tumor cells. Although the albumin is similar to alpha-fetoprotein in structure and believed to be derived from a common ancestral gene, HSA was not capable of altering the activities of PKA and the content of cAMP. In all our AFP studies, none of the results showed that HSA as a control was able to alter the parameters of cell proliferation although it can non-specifically bind to the cell surface. Moreover, monoclonal antibody against AFP could significantly reverse the effect of AFP, which implied that the accruing events in the intracellular signal transduction following binding of AFP to its receptor were specific.

Although growing evidences have verified the effects of AFP on the growth of tumor cells, little works were focused on the subsequent events in nucleus. The impacts of overexpression of protooncogenes on tumor growth have been largely documented. The previous works in our laboratory have been also shown an overexpression of p53 gene (data not shown). The other laboratory also demonstrated the alteration of related genes in malignant transformation of NIH 3T3 cells[16]. All there evidences indicated the alteration of expression of related genes. In this investigation, the expression of K-ras p21 gene was determined for its responsibility in AFP treatment. It was prevalent accepted that Kras $\mathrm{P} 21$ activates raf, which in turn passes the sig- 
nal through the intracellular signal regulated kinases to stimulate cell division, and that this pathway is upregulated when K-ras is mutated[17]. In fact, the alterations of K-ras p21 gene expression have been largely documented and related to tumor growth[18$20]$. In the present experiment, K-ras P21 protein was over produced in the presence of AFP. The finding indicates that the cell behavior induced by AFP was closely coupled with the change of K-ras gene expression. Thus, it thereby implied the mechanism by which the AFP-induced oncogenesis might be mediated through K-ras P21 signal pathways.

Collectively, the functionary mechanism of AFP on the tumor growth may be attributed, at least in part, to the receptor-mediated intracellular communication and the change of relative genes expression. Some other unknown factors which may also play key role in the effects of AFP need to be further characterized. Further investigations on the signal pathway will shed further light on the mechanism of AFP action.

\section{ACKNOWLEDGEMENTS}

This work was supported by National Natural Science Fundation of China (No. 39760077).

\section{REFERENCES}

[1] Toder V, Blank M, Gold-Gefter L, Nebel L. The effect of alpha-fetoprotein on the growth of placental cells in vitro. Placenta 1983; 4:79-86.

[2] Keel BA, Eddy KB, Cho S, May JV. Synergistic action of purified alpha-fetoprotein and growth factors on the proliferation of porcine granulosa cells in monolayer culture. Endocrinology 1991; 129(1):217-25.

[3] Wang W, Alpert E. Downregulation of phorbol 12myristate 13-acetate-induced tumor necrosis factor-alpha and interleukin-1 beta production and gene expression in human monocytic cells by human alphafetoprotein. Hepatology 1995; 22(3):921-8.

[4] Mizejewski GJ. Alpha-fetoprotein as a biologic response modifier: relevance to domain and subdomain structure. Proc Soc Exp Biol Med 1997; 215(4):333-62.

[5] Dudich E, Semenkova L, Gorbatova E, Dudich I, Khromykh L, Tatulov E, Grechko G, Sukhikh G. Growthregulative activity of human alpha-fetoprotein for different types of tumor and normal cells. Tumour Biol 1998; 19(1):30-40.

[6] Suzuki Y, Zeng CQY, Alpert E. Isolation and characterization of a specific alpha-fetoprotein receptor on human monocytes. J Clin Invest 1992; 90:530-6.
[7] Moro R, Tamaoki T, Wegmann TG, Longnecker BM, Laderoute MP. Monoclonal antibodies directed against a widespread oncofetal antigen: The alpha-fetoprotein receptor. Tumor Biol 1993; 14:116-30.

[8] Wang XW, Xu B. Stimulation of tumor-cell growth by alpha-fetoprotein. Int J Cancer 1998; 75:596-9.

[9] Ausubel FM, Brent R, Kingston RE, Moore DD eds. In: Short protocols in molecular biology. John Wiley and Sons: New York. 1996.

[10] Iwashita S, Mitsui KI, Shoji-kasai Y. cAMP-mediated modulation of signal transduction of epidermal growth factor (EGF) receptor system in human epidermoid carcinoma A431 cells. J Bio Chem 1990; 265:10702-8

[11] Park SK, Sedore SA, Cronmiller C and Hirsh J. Type II cAMP-dependent protein kinase-deficient drosophila are viable but show developmental, circadian, and drug response phenotypes. J Bio Chem 2000; 275(27):2058896.

[12] Ishikawa H, Nakata K, Tsuruta S, Nakao K, Kato Y, Tamaoki T, Eguchi K. Differential regulation of albumin gene expression by heparin-binding epidermal growth factor-like growth factor in -fetoprotein-producing and -nonproducing human hepatoma cells. Tumor Biol 1999; 20:130-8.

[13] Wang X. W, Xie H. Alpha-fetoprotein enhances the proliferation of human hepatoma cell in vitro. Life Science 1999; 64:17-23.

[14] Koide N, Nishio A, Igarashi J, Kajikawa S, Adachi W and Amano J. Alpha-fetoprotein-producing gastric cancer: histochemical analysis of cell proliferation, apoptosis, and angiogenesis. Am J Gastroenterol 1999; 94(6):1658-63.

[15] Torres JM, Geuskens M, Uriel J. Activated human T lymphocytes express albumin binding proteins which cross-react with alpha-fetoprotein. Eur J Cell Biol 1992; 57(2):222-8.

[16] Wadhwa R, Takano S, Mitsui Y, Kaul SC. NIH 3T3 cells malignantly transformed by mot-2 show inactivation and cytoplasmic sequestration of the p53 protein. Cell Res 1999; 9(4):261-9.

[17] Ramakrishna G, Sithanandam G, Cheng RY, Fornwald LW, Smith GT, Diwan BA, Anderson LM. K-ras p21 expression and activity in lung and lung tumors. Exp Lung Res 2000; 26(8):659-71.

[18] Komarova EA, Christov K, Faerman AI, Gudkov AV. Different impact of p53 and p21 on the radiation response of mouse tissues. Oncogene 2000; 19(33):3791-8.

[19] Kirla R, Salminen E, Huhtala S, Nuutinen J, Talve L, Haapasalo H, Kalim H. Prognostic value of the expression of tumor suppressor genes p53, p21, p16 and prb, and Ki-67 labelling in high grade astrocytomas treated with radiotherapy. J Neurooncol 2000; 46(1):71-80.

[20] Yuen PW, Lam KY, Choy JT, Ho WK, Wei WI. Clinicopathological significance of p53 and p21 expression in the surgical treatment of laryngeal carcinoma. Anticancer Res $2000 ; \mathbf{2 0}(\mathbf{6 C}): 4863-6$. 